\title{
Metformin: A stroke of luck
}

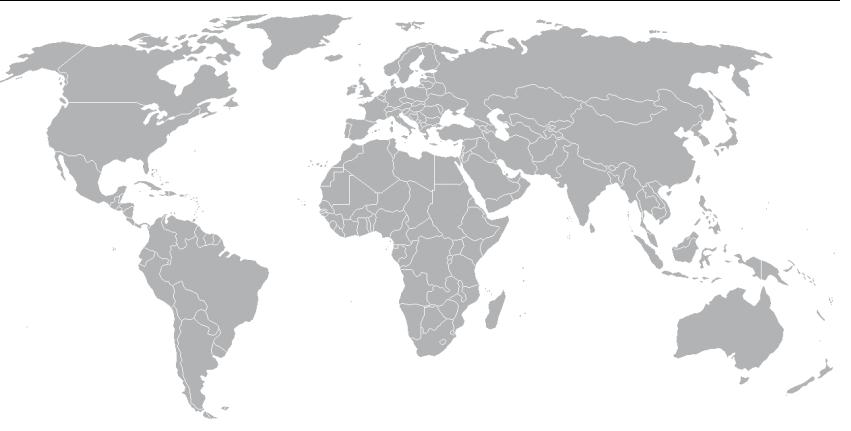

Mohamad Aljofan¹, Abduzhappar Gaipov²

\section{ABSTRACT}

Metformin is an oral glucose-lowering drug that has been widely used for more than half a century. Both the American Diabetes Association and the European Association for the study of Diabetes recommend metformin as the first line therapy for the treatment of type II diabetes mellitus. Metformin has considerably evolved from being an antidiabetic into a drug with a wider potential of therapeutic uses such as anticancer, antiaging, treatment of gestational hypertension, preeclampsia and weight loss. In addition to the in-label use of metformin as an anti-hyperglycemic medication, it is widely prescribed as an off label therapy for young women with Poly Cystic Ovary Syndrome for the treatment of symptoms associated with the disorder. This article is a brief summary that lists and briefly discusses current and potential non-hyperglycemic uses and effects of metformin.

Keywords: metformin, PCOS, cancer, cardiovascular, mechanism of action

\section{INTRODUCTION}

Glucophage, literally glucose eater, is the name that the French Scientist Jean Sterne gave to metformin in the 1950s. Since then, the drug is used for the treatment of diabetes and it is the recommended first line treatment of type II diabetes mellitus. Traditionally, it is believed that metformin improves glycaemia by acting on the liver via AMPK activation. However, there is a growing evidence suggest that metformin has other target organs including the gut and intestines (1).

In 2010, approximately 50 million metformin prescriptions were issued in the United Sates alone (2). While these prescriptions were not for diabetes only, the number is likely to increase as more uses of metformin are reported. For instance, numerous studies have indicated the potential and different uses of metformin including the treatment/prevention of several types of cancer, anti-ageing, cardiovascular protection, and neurological disorders (3).

Also, various studies have indicated that long-term administration of metformin reduces the risk of various types of cancer, including breast, colon and endometrial cancer, and glioma $(4,5)$. Furthermore, a number of studies showed that metformin can inhibit cell proliferation, induce cell death in various types of cancer cells, and increase the survival rate of diabetic patients with cancer (6). Currently, tens of clinical trials are undergoing to test various therapeutic potentials of metformin including trials that aim to investigate its potential anticancer activity against endometrial, prostate, pancreas, lung and breast cancer (1).

The current uses of metformin, both in-label and off label, include antidiabetic and extends to anti-ageing as well. Therefore, listing all of the current and potential uses might not be feasible, however, the current manuscript is a review that lists and briefly discusses some of the different reported non-hyperglycemic clinical uses of metformin.

\section{METFORMIN AND CANCER}

People with diabetes have a mortality rate 3-4 times that of the general population (7) and an increased risk of several common cancers with an estimated incidence rate of about 1.2 times higher than that of non-diabetics $(8,9)$. However, a number of reports have suggested that metformin, which is frequently prescribed to reduce hepatic gluconeogenesis

\footnotetext{
Department of Biomedical Sciences, Nazarbayev University School of Medicine. Nur-Sultan city, Kazakhstan.

2 Department of Clinical Sciences, Nazarbayev University School of Medicine. NurSultan city, Kazakhstan
}

Received: 18 Apr 2019, Accepted: 21 Apr 2019

\section{Correspondence: Mohamad Aljofan \\ Department of Biomedical Sciences, Nazarbayev University School of Medicine. Nur- Sultan city, Kazakhstan.}

E-mail: mohamad.aljofan@nu.edu.kz

(C) 2019 by the authors; licensee Modestum Ltd., UK. This article is an open access article distributed under the terms and conditions of the Creative Commons Attribution License (http://creativecommons.org/licenses/by/4.0/). 


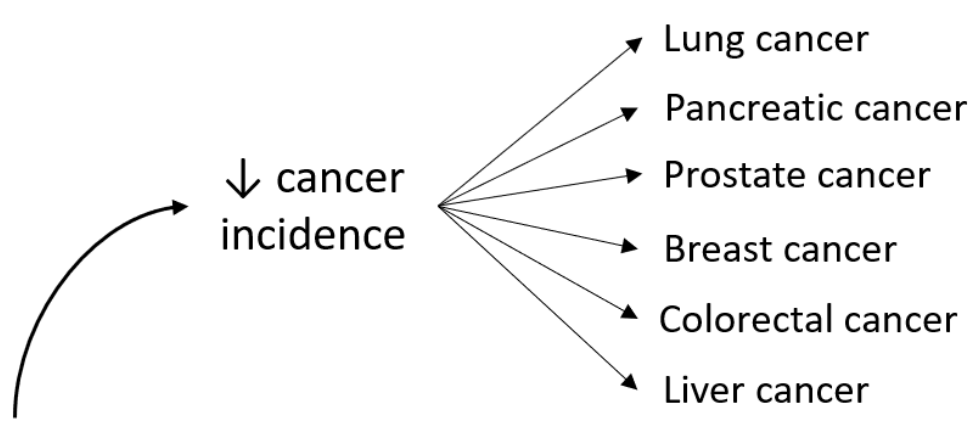

METFORMIN
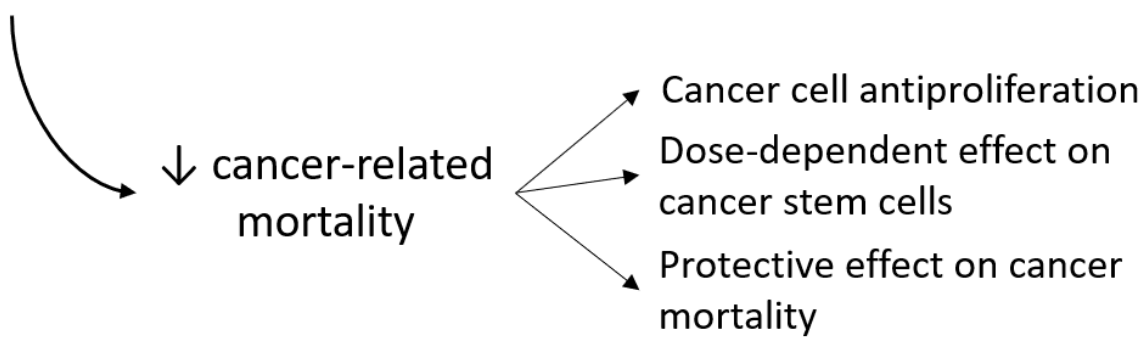

Figure 1: Metformin and cancer prevention

and increase skeletal muscle glucose uptake in patients with type 2 diabetes could also potentially provide antiproliferative effects against several cancers (Figure 1).

Evidence from in vitro, in vivo as well as epidemiological and observational studies suggest that metformin may not only prevent diabetes, but can actually be an important adjuvant for cancer therapy. Some of the published observational studies have reported a link between the use of metformin and reduced risk of cancers and cancer related deaths, including a study by Evans et al. which reported that metformin is associated with reduced risk of cancer in patients with type 2 diabetes and that the association appears to be in a dose-response relationship (4). Similarly, a retrospective study involving a diabetics cohort of more than 10,000 newly treated for type 2 diabetes and were followed for about 5 years, suggested that patients exposed to metformin were significantly less likely to have a cancer related death compared to diabetics on other treatments (10).

Equally, a meta-analysis study in Taiwan that looked at the association between lung cancer and metformin treatment, concluded that the metformin use in type 2 diabetes patients may significantly reduce the risk of lung cancer, and that the antitumor protective mechanism of metformin was significantly higher for patients who used the drug for more than 4 years (5).

There is an increasing interest in studying the effect of metformin against different types of cancer. For example, a study by Li and colleagues reported a hospital-based case control study that investigated the effect of anti-diabetic therapies on pancreatic cancer. The authors suggested that diabetics who used metformin, particularly those who have prolonged usage (five or more years), had a reduced risk of pancreatic cancer compared to those who never used it (11). The study claimed that the risk of pancreatic cancer in metformin group was $62 \%$ lower than in the placebo group.

A meta-analysis result from a systematic review of the effect of metformin use on various prostate cancer outcomes in patients with type 2 diabetes revealed that metformin use is associated with a $20 \%$ decrease in risk of recurrence in prostate cancer patients with concurrent type 2 diabetes (12). An observational study reported that metformin treatment was associated with an improved response among early stage breast cancer patients receiving neoadjuvant therapy, and that the drug was tested for its potential effect on breast cancer proliferation and follow up trials are planned (6).

Furthermore, laboratory studies showed that metformin was able to inhibit cell proliferation, reduce colony formation, and cause partial cell cycle arrest in cancer cell lines (6). An in vitro study by Sabit et al., suggested that a cellular concentration of $100 \mathrm{mM}$ of metformin resulted in more than $85 \%$ reduction in breast cancer (MCF-7) cell viability while treatment of colon cancer cells (CaCo-2) with a concentration of $5 \mathrm{mM}$ was enough to achieve as high as $97 \%$ cell cancer mortality (13). The authors suggested that colorectal cancer cells were very sensitive to metformin even at low doses. Another in vitro study by Safari et al., reported that breast cancer cells treated with a cellular concentration of $10 \mathrm{mM}$ of metformin resulted in the highest cellular apoptotic rate (14), which further confirms the sensitivity of cancer cells to metformin. 
One of the earliest in vivo studies that investigated the anti-tumorigenesis effect of metformin was reported by Rattan et al. (15). They described the effect of metformin enhanced cisplatin on ovarian cancer model using IP-induced A2780 xenograft in nude female mice. The study reported a number of interesting findings including xenografts treated with metformin showed reduced tumor burden, reduced angiogenesis, and metastatic potentials compared with untreated mice (15).

\section{MECHANISM OF ACTION OF ANTICANCER ACTIVITY}

Metformin's anti-tumorigenesis mechanism of action are not fully understood as to whether metformin acts directly on the growing tumor, or is the effect due its ability to change host physiology or both of these mechanisms combined. However, a number of studies have suggested several different mechanisms for example, a study by Li and colleagues postulated that the anticancer effect of metformin occurs both at the cellular and at the organism levels simultaneously (11).

We believe that this hypothesis may in part be true, but given the fact that metformin was reported to effect specific type of cancers and not others may suggest that its activity is likely achieved on a cellular level rather than organism.

Several studies reported possible mechanisms of action of antitumor activity of metformin, including the suppression of cancer cell metabolism (16), inhibition of mammalian target of rapamycin (mTOR) (1), tumor angiogenesis inhibition (16), immunomodulation such as increasing the number of $C D 8^{+}$tumor-infiltrating lymphocytes $(17,18)$, and activation of tumor apoptosis and autophagy (19).

However, in vivo studies show that metformin has a reduced antitumor activity on control diet mice than it does on a high-energy diet mice associated with hyperinsulinemia and accelerated tumor growth (20), indicating that the insulin reducing action of metformin may contribute to its antitumor activity, and that it may have less effect on cancers in less hyperinsulinemic patients (6).

Therefore, based on the reported mechanisms of action of metformin, its different pharmacological efficacy and multiple target sites, we can speculate that the antineoplastic activity of metformin is more likely to be an outcome of a collective simultaneous mechanisms primarily through its activity on hyperglycemia.

\section{CARDIOVASCULAR PROTECTIVE EFFECT}

While reducing glucose level may not necessarily reduce cardiovascular events (21), surely, the effect of metformin on glycemic control will result either directly or indirectly in improved macrovascular protection. Numerous studies have shown the beneficial effect of metformin on cardiovascular including; a trial involving type 2 diabetic patients who received a three months therapy of metformin treatment compared to placebo, which showed that the metformin treated group displayed improved endothelium-dependent vascular responses, whereas vascular responses of patients treated with placebo remained unchanged $(22,23)$. Also, patients with ischemic cardiomyopathy, who were treated with metformin had reduced rates of re-infarction, occurrence of angina pectoris, and acute coronary (24). Additionally, metformin treated patients showed improved endothelial function (25) and in vitro studies reported that metformin has a direct protective action on the vascular endothelium (26).

The exact mechanism of how metformin exerts its protective cardiovascular mechanisms remains unsolved with various possible mechanisms were reported; including that metformin treatment will lead to improvement in coagulation, oxidative stress (27), endothelial dysfunction $(26,27)$, and inflammatory pathway (24).

\section{POLYCYSTIC OVARY SYNDROME}

Polycystic ovary syndrome (PCOS) is a complex metabolic disorder and the most common endocrine disorder in reproductive-age women that affects between $5-20 \%$ of this age group (28). The clinical expression of PCOS varies but commonly includes oligo-ovulation or anovulation, hyperandrogenism (either clinical or biochemical), and the presence of polycystic ovaries (29). Typically, patients may present with a combination of hyperandrogenism symptoms, menstrual irregularities, metabolic syndrome, infertility, acne, and obesity (30).

While there is no available treatment for PCOS, different therapies have been used to improve the symptoms associated with PCOS, including metformin, which has been recognized as the most preferred treatment modality for PCOS (Figure 2). While, the exact mechanism of action of metformin in patients with PCOS remain unknown, it has been extensively prescribed for child-bearing age women with PCOS. 


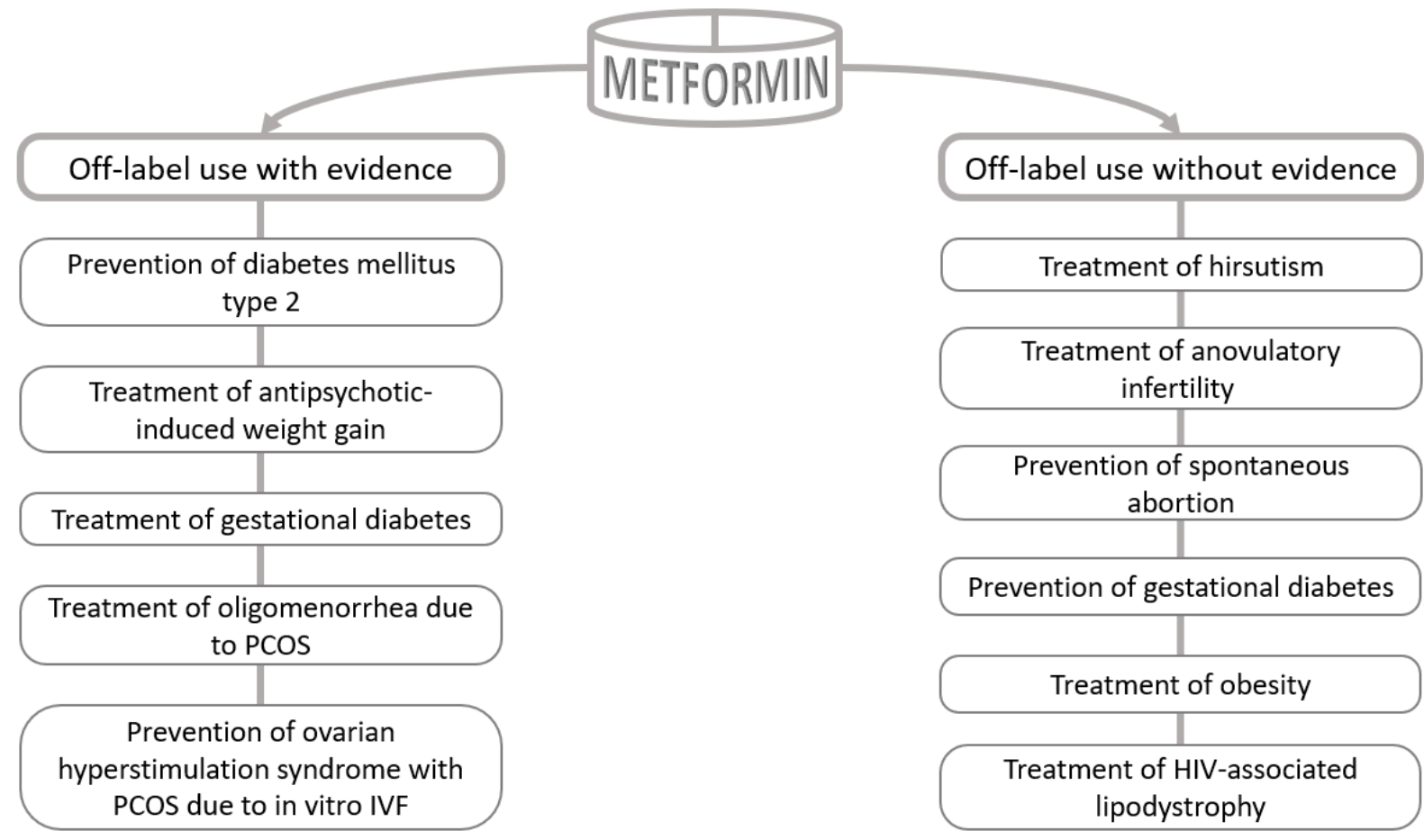

Figure 2: Off-label usage of Metformin

One possible mechanism of action of how metformin improves PCOS symptoms is thought to be through its effect on reducing the circulating levels of androgens and body weight, which eventually manages the symptoms and cysts (31). Lowering the circulating levels of androgen will lead to the alleviation of other PCOS symptoms such as relief in acne and hirsutism, improvement in the occurrence of mood swings, reduction/resolution of menstrual irregularities, and enhancement of ovulation (32).

Also, insulin resistance and the associated compensatory hyperinsulinaemia, are likely to be an important contributing factor in the pathogenesis of PCOS, thus metformin and other insulin-sensitizing drugs were introduced as a treatment option (33).

Furthermore, metformin produces a general action on glucose regulation metabolism by insulin (34), and insulin resistance values are good predictors of the efficacy of metformin treatment (35), suggesting that metformin might act to induce ovulation as a result of the improved metabolic control.

Moreover, it was reported that women with PCOS are at higher risk of miscarriage in the early months of pregnancy as are women without PCOS $(36,37)$. While there are conflicting results in the use of metformin during pregnancy, some research shows that metformin may reduce the risk of miscarriage in pregnant women with PCOS without an increase in the rate of fetal malformation $(35,36)$. The findings of a meta-analysis by Cassina et al. that was based on metformin exposure in 351 women with PCOS indicated that there is no increase in congenital anomaly with metformin use in pregnancy (38).

Furthermore, analyses of nine randomized trials including 816 women with PCOS by Lo et al, reported that metformin increased clinical pregnancy rates and decreased the risk of ovarian hyperstimulation syndrome (39). Likewise, the use of metformin throughout pregnancy in women with polycystic ovary syndrome decreases the rates of early pregnancy loss and preterm labor; hence protecting against fetal growth restriction (34).

Several animal studies found that metformin might stimulate ATP production, which serve as an important source of energy for the growing oocyte (40). Another in vivo study by Martin et al., suggested that metformin leads to an increase usage of lipids and $\beta$-oxidation of fatty acids that serve as an energy source for oocyte maturation and early embryo development (41). Additional protective effect of metformin on embryo development was reported by Huang et al., which suggested that metformin use by Dehydroepiandrosterone treated mice, which resemble some characters of human PCOS, such as irregular sexual cycles and polycystic ovaries, showed reduced oxidative stress and increase antioxidant defense in oocytes (42). 


\section{MISCELLANEOUS}

Several studies have been reported the off-label usage of metformin in different clinical settings (Figure 2). As we mentioned above, metformin was found to be effective in managing various symptoms related to PCOS including; oligomenorrhea; and the prevention of ovarian hyperstimulation syndrome in women undergoing in vitro fertilization (IVF)/intracytoplasmic sperm injection (43). However, in some cases, such as hirsutism caused by PCOS and anovulatory infertility in women with PCOS, the routine use of metformin less favored due to lack of supportive evidence $(43,44)$. Furthermore, there is insufficient evidence that metformin may induce ovulation; prevent miscarriage, multiple gestations, and pregnancy complications (e.g. prevention of spontaneous abortion and gestational diabetes) in women with PCOS (45).

Recently, the American Diabetes Association guidelines suggested metformin therapy could be used for the prevention of type 2 diabetes in patients with prediabetes, with $\mathrm{BMI} \geq 35 \mathrm{~kg} / \mathrm{m} 2$, aged $<60$ years, and women with prior gestational diabetes mellitus (46).

Metformin was found to be clinically effective in the treatment of obesity, obesity related insulin resistance and metabolic syndrome due to antipsychotic-induced weight gain (47). Other observed uses of metformin include antiaging, anti-inflammatory and cardio-protective effects were reported in several studies, which need to be further confirmed in randomized clinical trials (48).

\section{CONCLUSION}

There is an increasing interest in the use of metformin as a potential treatment for different types of cancer. The widely used and well tolerated drug was reported in observational, laboratory and animal studies to have some antineoplastic activities through not yet known mechanisms. In this review, we reported some of the current and potential non-hyperglycemic uses of metformin. If proven, the reasonably safe and affordable metformin would make an ideal anticancer agent that can be used as an adjuvant to standard treatment, a monotherapy, or combined with other chemotherapeutics for the treatment of cancer.

\section{REFERENCES}

1. Chae YK, Arya A, Malecek MK, Shin DS, Carneiro B, Chandra S, et al. Repurposing metformin for cancer treatment: current clinical studies. Oncotarget. 2016;7(26):40767-80. https://doi.org/10.18632/oncotarget.8194 PMid:27004404 PMCid:PMC5130043

2. Breitenstein MK, Simon G, Ryu E, Armasu SM, Weinshilboum RM, Wang L, et al. Using EHR-Linked Biobank Data to Study Metformin Pharmacogenomics. Stud Health Technol Inform. 2015;210:914-8. https://doi.org/10.3233/978-1-61499-512-8-914 PMID:25991289

3. El-Arabey AA. Update on off label use of metformin for obesity. Prim Care Diabetes. 2018;12(3):284-5. https://doi.org/10.1016/j.pcd.2018.02.004 PMid:29525383

4. Evans JM, Donnelly LA, Emslie-Smith AM, Alessi DR, Morris AD. Metformin and reduced risk of cancer in diabetic patients. BMJ. 2005;330(7503):1304-5. https://doi.org/10.1136/bmj.38415.708634.F7 PMid:15849206 PMCid:PMC558205

5. Tseng $\mathrm{CH}$. Metformin and lung cancer risk in patients with type 2 diabetes mellitus. Oncotarget. 2017;8(25):41132-42. https://doi.org/10.18632/oncotarget.17066 PMid:28456789 PMCid:PMC5522244

6. Giovannucci E, Harlan DM, Archer MC, Bergenstal RM, Gapstur SM, Habel LA, et al. Diabetes and cancer: a consensus report. Diabetes Care. 2010;33(7):1674-85. https://doi.org/10.2337/dc10-0666 PMid:20587728 PMCid:PMC2890380

7. Ding $\mathrm{H}$, Aljofan $\mathrm{M}$, Triggle $\mathrm{CR}$. Oxidative stress and increased eNOS and NADPH oxidase expression in mouse microvessel endothelial cells. J Cell Physiol. 2007;212(3):682-9. https://doi.org/10.1002/jcp.21063 PMid:17443690

8. Reinehr T, Kiess W, Kapellen T, Andler W. Insulin sensitivity among obese children and adolescents, according to degree of weight loss. Pediatrics. 2004;114(6):1569-73. https://doi.org/10.1542/peds.2003-0649-F PMid:15574616

9. Tock L, Damaso AR, de Piano A, Carnier J, Sanches PL, Lederman HM, et al. Long-term effects of metformin and lifestyle modification on nonalcoholic Fatty liver disease obese adolescents. J Obes. 2010;2010. https://doi.org/10.1155/2010/831901 PMid:20798858 PMCid:PMC2925435 
10. Bowker SL, Majumdar SR, Veugelers P, Johnson JA. Increased cancer-related mortality for patients with type 2 diabetes who use sulfonylureas or insulin: Response to Farooki and Schneider. Diabetes Care. 2006;29(8):19901. https://doi.org/10.2337/dc06-0997 PMid:16873829

11. Li D, Yeung SC, Hassan MM, Konopleva M, Abbruzzese JL. Antidiabetic therapies affect risk of pancreatic cancer. Gastroenterology. 2009;137(2):482-8. https://doi.org/10.1053/j.gastro.2009.04.013 PMid:19375425 PMCid:PMC2735093

12. Hwang IC, Park SM, Shin D, Ahn HY, Rieken M, Shariat SF. Metformin association with lower prostate cancer recurrence in type 2 diabetes: a systematic review and meta-analysis. Asian Pac J Cancer Prev. 2015;16(2):595600. https://doi.org/10.7314/APJCP.2015.16.2.595 PMid:25684493

13. Sabit H, Abdel-Ghany SE, OA MS, Mostafa MA, El-Zawahry M. Metformin Reshapes the Methylation Profile in Breast and Colorectal Cancer Cells. Asian Pac J Cancer Prev. 2018;19(10):2991-9. https://doi.org/10.22034/APJCP.2018.19.10.2991 PMID:30371994 PMCID:PMC6291041

14. Safari Z, Safaralizadeh $R$, Seyedzadeh $M H$, Valinezad Orang A, Zare A, Hosseinpour Feizi MA, et al. The Induction of Metformin Inhibitory Effects on Tumor Cell Growth in Hypoxic Condition. Iran J Allergy Asthma Immunol. 2015;14(6):605-14. PMID:26725558

15. Rattan R, Graham RP, Maguire JL, Giri S, Shridhar V. Metformin suppresses ovarian cancer growth and metastasis with enhancement of cisplatin cytotoxicity in vivo. Neoplasia. 2011;13(5):483-91. https://doi.org/10.1593/neo.11148 PMid:21532889 PMCid:PMC3084625

16. Wang J, Li G, Wang Y, Tang S, Sun X, Feng X, et al. Suppression of tumor angiogenesis by metformin treatment via a mechanism linked to targeting of HER2/HIF-1alpha/VEGF secretion axis. Oncotarget. 2015;6(42):44579-92. https://doi.org/10.18632/oncotarget.6373 PMid:26625311 PMCid:PMC4792577

17. Eikawa S, Nishida M, Mizukami S, Yamazaki C, Nakayama E, Udono H. Immune-mediated antitumor effect by type 2 diabetes drug, metformin. Proc Natl Acad Sci U S A. 2015;112(6):1809-14. https://doi.org/10.1073/pnas.1417636112 PMid:25624476 PMCid:PMC4330733

18. Aljofan M, Lo MK, Rota PA, Michalski WP, Mungall BA. Off Label Antiviral Therapeutics for Henipaviruses: New Light Through Old Windows. J Antivir Antiretrovir. 2010;2(1):1-10. https://doi.org/10.4172/jaa.1000014 PMID:20668647 PMCID:PMC2910441

19. Nazim UM, Moon JH, Lee JH, Lee YJ, Seol JW, Eo SK, et al. Activation of autophagy flux by metformin downregulates cellular FLICE-like inhibitory protein and enhances TRAIL- induced apoptosis. Oncotarget. 2016;7(17):23468-81. https://doi.org/10.18632/oncotarget.8048 PMid:26992204 PMCid:PMC5029640

20. Algire C, Zakikhani M, Blouin MJ, Shuai JH, Pollak M. Metformin attenuates the stimulatory effect of a highenergy diet on in vivo LLC1 carcinoma growth. Endocr Relat Cancer. 2008;15(3):833-9. https://doi.org/10.1677/ERC-08-0038 PMid:18469156

21. Ding $\mathrm{H}$, Ye K, Triggle CR. Impact of currently used anti-diabetic drugs on myoendothelial communication. Curr Opin Pharmacol. 2018;45:1-7. https://doi.org/10.1016/j.coph.2018.11.002 PMid:30502742

22. Chan NN. Improved endothelial function with metformin in type 2 diabetes mellitus. J Am Coll Cardiol. 2001;38(7):2131-2. https://doi.org/10.1016/S0735-1097(01)01631-X

23. Mather KJ, Verma S, Anderson TJ. Improved endothelial function with metformin in type 2 diabetes mellitus. J Am Coll Cardiol. 2001;37(5):1344-50. https://doi.org/10.1016/S0735-1097(01)01129-9

24. Rojas LB, Gomes MB. Metformin: an old but still the best treatment for type 2 diabetes. Diabetol Metab Syndr. 2013;5(1):6. https://doi.org/10.1186/1758-5996-5-6 PMid:23415113 PMCid:PMC3607889

25. Feng $Y$, Ke C, Tang Q, Dong H, Zheng X, Lin W, et al. Metformin promotes autophagy and apoptosis in esophageal squamous cell carcinoma by downregulating Stat3 signaling. Cell Death Dis. 2014;5:e1088. https://doi.org/10.1038/cddis.2014.59 PMid:24577086 PMCid:PMC3944271

26. Samuel SM, Ghosh S, Majeed Y, Arunachalam G, Emara MM, Ding H, et al. Metformin represses glucose starvation induced autophagic response in microvascular endothelial cells and promotes cell death. Biochem Pharmacol. 2017;132:118-32. https://doi.org/10.1016/j.bcp.2017.03.001 PMid:28274614

27. Aljofan $M$, Ding $H$. High glucose increases expression of cyclooxygenase-2, increases oxidative stress and decreases the generation of nitric oxide in mouse microvessel endothelial cells. J Cell Physiol. 2010;222(3):66975. https://doi.org/10.1002/jcp.21986 PMid:19950211

28. Norman RJ, Teede HJ. A new evidence-based guideline for assessment and management of polycystic ovary syndrome. Med J Aust. 2018;209(7):299-300. https://doi.org/10.5694/mja18.00635 PMid:30257632 
29. Norman RJ, Dewailly D, Legro RS, Hickey TE. Polycystic ovary syndrome. Lancet. 2007;370(9588):685-97. https://doi.org/10.1016/S0140-6736(07)61345-2

30. Pfieffer ML. Polycystic ovary syndrome: Diagnosis and management. Nurse Pract. 2019. https://doi.org/10.1097/01.NPR.0000553398.50729.c0 PMid:30695006

31. Sirmans SM, Pate KA. Epidemiology, diagnosis, and management of polycystic ovary syndrome. Clin Epidemiol. 2013;6:1-13. https://doi.org/10.2147/CLEP.S37559 PMid:24379699 PMCid:PMC3872139

32. Artani M, Iftikhar MF, Khan S. Effects of Metformin on Symptoms of Polycystic Ovarian Syndrome Among Women of Reproductive Age. Cureus. 2018;10(8):e3203. https://doi.org/10.7759/cureus.3203 PMid:30410828 PMCid:PMC6207166

33. Dunaif A. Insulin resistance and the polycystic ovary syndrome: mechanism and implications for pathogenesis. Endocr Rev. 1997;18(6):774-800. https://doi.org/10.1210/edrv.18.6.0318 PMid:9408743

34. Palomba S, Falbo A, Zullo F, Orio F, Jr. Evidence-based and potential benefits of metformin in the polycystic ovary syndrome: a comprehensive review. Endocr Rev. 2009;30(1):1-50. https://doi.org/10.1210/er.2008-0030 PMid:19056992

35. Palomba S, Pasquali R, Orio F, Jr., Nestler JE. Clomiphene citrate, metformin or both as first-step approach in treating anovulatory infertility in patients with polycystic ovary syndrome (PCOS): a systematic review of headto-head randomized controlled studies and meta-analysis. Clin Endocrinol (Oxf). 2009;70(2):311-21. https://doi.org/10.1111/j.1365-2265.2008.03369.x PMid:18691273

36. Boomsma CM, Fauser BC, Macklon NS. Pregnancy complications in women with polycystic ovary syndrome. Semin Reprod Med. 2008;26(1):72-84. https://doi.org/10.1055/s-2007-992927 PMid:18181085

37. Paule $S$, Aljofan $M$, Simon $C$, Rombauts $L$, Nie G. Cleavage of endometrial alpha-integrins into their functional forms is mediated by proprotein convertase 5/6. Hum Reprod. 2012;27(9):2766-74. https://doi.org/10.1093/humrep/des203 PMid:22740495

38. Cassina $M$, Dona $M, D i$ Gianantonio $E$, Litta $P$, Clementi $M$. First-trimester exposure to metformin and risk of birth defects: a systematic review and meta-analysis. Hum Reprod Update. 2014;20(5):656-69. https://doi.org/10.1093/humupd/dmu022 PMid:24861556

39. Tso LO, Costello MF, Albuquerque LE, Andriolo RB, Freitas V. Metformin treatment before and during IVF or ICSI in women with polycystic ovary syndrome. Cochrane Database Syst Rev. 2009(2):CD006105. https://doi.org/10.1002/14651858.CD006105.pub2

40. Richardson MC, Ingamells S, Simonis CD, Cameron IT, Sreekumar R, Vijendren A, et al. Stimulation of lactate production in human granulosa cells by metformin and potential involvement of adenosine $5^{\prime}$ monophosphateactivated protein kinase. J Clin Endocrinol Metab. 2009;94(2):670-7. https://doi.org/10.1210/jc.2008-2025 PMid: 19001513

41. Martin-Montalvo A, Mercken EM, Mitchell SJ, Palacios HH, Mote PL, Scheibye-Knudsen $\mathrm{M}$, et al. Metformin improves healthspan and lifespan in mice. Nat Commun. 2013;4:2192. https://doi.org/10.1038/ncomms3192 PMid:23900241 PMCid:PMC3736576

42. Huang Y, Yu Y, Gao J, Li R, Zhang C, Zhao H, et al. Impaired oocyte quality induced by dehydroepiandrosterone is partially rescued by metformin treatment. PLoS One. 2015;10(3):e0122370. https://doi.org/10.1371/journal.pone.0122370 PMid:25811995 PMCid:PMC4374838

43. American Association of Clinical Endocrinologists Polycystic Ovary Syndrome Writing C. American Association of Clinical Endocrinologists Position Statement on Metabolic and Cardiovascular Consequences of Polycystic Ovary Syndrome. Endocr Pract. 2005;11(2):126-34. https://doi.org/10.4158/EP.11.2.125 PMid:15915567

44. Barbieri RL. Metformin for the treatment of polycystic ovary syndrome. Obstet Gynecol. 2003;101(4):785-93. https://doi.org/10.1016/S0029-7844(03)00045-0 PMid:12681887

45. Practice Committee of the American Society for Reproductive Medicine. Electronic address Aao, Practice Committee of the American Society for Reproductive M. Role of metformin for ovulation induction in infertile patients with polycystic ovary syndrome (PCOS): a guideline. Fertil Steril. 2017;108(3):426-41. https://doi.org/10.1016/j.fertnstert.2017.06.026 PMID:28865539

46. American Diabetes A. 5. Prevention or Delay of Type 2 Diabetes: Standards of Medical Care in Diabetes-2018. Diabetes Care. 2018;41(Suppl 1):S51-S4. https://doi.org/10.2337/dc18-S005 PMid:29222376 
47. Handen BL, Anagnostou E, Aman MG, Sanders KB, Chan J, Hollway JA, et al. A Randomized, Placebo-Controlled Trial of Metformin for the Treatment of Overweight Induced by Antipsychotic Medication in Young People With Autism Spectrum Disorder: Open-Label Extension. J Am Acad Child Adolesc Psychiatry. 2017;56(10):849-56 e6. https://doi.org/10.1016/j.jaac.2017.07.790 PMid:28942807

48. Mahmood K, Naeem M, Rahimnajjad NA. Metformin: the hidden chronicles of a magic drug. Eur J Intern Med. 2013;24(1):20-6. https://doi.org/10.1016/j.ejim.2012.10.011 PMid:23177353

49. Initial management of blood glucose in adults with type 2 diabetes mellitus [Internet]. Uptodate. Jan 2019 [cited 22 Feb 2019].

$\diamond \diamond \diamond \diamond \diamond \diamond \diamond$

http://www.ejgm.co.uk 